\title{
FAKTOR MATERNAL DAN POLA MAKAN DENGAN KEJADIAN KEKURANGAN ENERGI KRONIK PADA IBU HAMIL DI WILAYAH KERJA UPTD PUSKESMAS KANGKUNG
}

\author{
Hanifatul Hikmah ${ }^{\bowtie}$, Yuni Puji W, Istioningsih \\ Program Studi Ilmu Keperawatan STIKES Kendal
}

\begin{tabular}{l}
\hline ARTICLE INFO \\
\hline Article history \\
Submitted : 2020-01-24 \\
Revised : 2020-01-27 \\
Accepted : 2020-01-31 \\
Keywords: \\
Chronic Energy Deficiency \\
Diet \\
Maternal Factors \\
Pregnant mother
\end{tabular}

\section{Kata Kunci:}

Kekurangan Energi Kronik Pola makan

Faktor Maternal

Ibu hamil

\begin{abstract}
Health problem of pregnant women are still often as ahealth problem in Indonesia. This is because it still exceeds the Maternal Mortality Rate (MMR) due t bleeding, eclampsia, unsafe abortion, prolonged labor, and infection. Another factor thar increases MMR is the poor nutrition of women, known as anemia and Chronic Energy Deficieny (KEK) which have an impact with fetal health and well-being. The purpose of this study was to determine the relationship between Factor Characteristics, Maternal Factors and Eating Patterns and Chronic Energy Deficiency (CED) Events in Pregnant Women. This study used a correlational descriptive design, with cross sectional approach. The sampling technique is Non Probability Sampling with a sample of 150 pregnant women. Results shows there was a significant relationship between the age of pregnant women ( $p$ value of 0.002 ), parity ( $p$ value of 0.011 ), education ( $p$ value of 0,000 ), the history of complications ( $p$ value of 0.030 ), eating patterns ( $p$ value of 0,000 ), and the incidence of CED. There is no significant relationship between maternal family income and the incidence of CED, the p value is 0.063 . Research result prove there are still $10,7 \%$ of pregnant women who spend Chronic Energy Deficiency and there are 10,7\% of those who have poor diet, expect pregnant women to pay attention and meet their nutritional needs, to avoid Chronic Energy Deficiency (CED) and be active in finding information and asking lots of questions that understand more about health, especially related to Chronic Energy Deficiency problems.

Masalah kesehatan ibu hamil masih sering menjadi masalah kesehatan di Indonesia. Hal ini dikarenakan masih tingginya Angka Kematian Ibu (AKI) disebabkan oleh perdarahan, eklamsia, aborsi tidak aman (unsafe abortion), partus lama, dan infeksi. Faktor lain yang meningkatkan Angka Kematian Ibu (AKI) adalah buruknya gizi perempuan, yang dikenal dengan anemia dan Kekurangan Energi Kronik (KEK) yang berdampak terhadap kesehatan dan kesejahteraan janin. Tujuan dari penelitian ini untuk mengetahui Hubungan Faktor Karakteristik, Faktor Maternal dan Pola Makan Dengan Kejadian Kekurangan Energi Kronik Pada Ibu Hamil. Penelitian ini menggunakan Desain deskriptif korelasional dengan pendekatan Cross Sectional. Teknik pengambilan sampel dengan Non Probility Sampling dengan sampel berjumlah 150 ibu hamil. Hasil penelitian menunjukkan ada hubungan yang signifikan antara usia ibu hamil ( $p$ value $0,002)$, paritas ( $p$ value 0,011$)$, pendidikan ( $p$ value 0,000$)$, riwayat penyakit penyerta ( $p$ value 0,030 ), pola makan ( $p$ value 0,000 ) dengan kejadian KEK. Tidak ada hubungan antara pendapatan keluarga dengan kejadian KEK diperoleh nilai $p$ value yaitu 0,063. Hasil penelitian menunjukkan masih terdapat $10,7 \%$ ibu hamil yang mengalami KEK dan terdapat $10,7 \%$ yang memiliki pola makan buruk, maka diharapkan ibu hamil untuk memperhatikan dan memenuhikebutuhan gizinya, agar terhindar dari KEK danaktif dalam mencari informasi dan banyak bertanya yang lebih paham tentangkesehatan khususnya terkait masalah KEK.
\end{abstract}

$\triangle$ Corresponding Author:

Hanifatul Hikmah

Program Studi Ilmu Keperawatan STIKES Kendal

Telp. 085868274715

Email: hanifatulhikmah96@gmail.com

\section{PENDAHULUAN}

Sustainable Development Gols (SDGs) merupakan lanjutan dan penyempurnaan dari MDGs yang telah berakhir pada tahun 2015 .
Salah satu dari 17 tujuan SDGs menyangkut kesehatan yaitu menjamin kehidupan yang sehat dan mendorong kesejahteraan bagi semua orang di segala usia (Sustainable Development, 
2016). Banyak target yang harus dicapai 2030 mendatang diantaranya mengurangi kelahiran prematur, progam perencanaan keluarga, mencegah kematian balita, mengurangi rasio kematian ibu dan sederet panjang lainnya yang berhubungan di bidang kesehatan.

Masalah kesehatan ibu hamil masih sering menjadi masalah kesehatan di Indonesia. Hal ini dikarenakan masih tingginya Angka Kematian Ibu (AKI) disebabkan oleh perdarahan, eklamsia, aborsi tidak aman (unsafe abortion), partus lama, dan infeksi. Faktor lain yang meningkatkan Angka Kematian Ibu (AKI) adalah buruknya gizi perempuan, yang dikenal dengan anemia dan Kekurangan Energi Kronik (KEK) (Aisyah, 2013).

Kekurangan energi kronik adalah keadaan dimana status gizi seseorang buruk disebabkan karena kekurangnya asupan pangan sumber energi yang mengandung zat gizi makro yang berlangsung lamaatau menahun. Pola konsumsi makan ibu hamil dipengaruhi pola konsumsi keluarga dan distribusi makanan yang terdiri dari jumlah, jenis, frekuensi, serta pantangan makan. Pantangan dalam mengkonsumsi jenis makanan tertentu dapat dipengaruhi oleh faktor budaya atau kepercayaan yang terdapat dalam masyarakat setempat. Pola makan yang baik perlu dibentuk sebagai upaya memenuhi kebutuhan gizi, terutama ibu hamil yang mengalami kekurangan energi kronik (Oktriyani, 2014). Tanda ibu hamil yang mengalami Kekurangan Energi Kronik yaitu ditandai dengan Lingkar Lengan Atas (LiLA) di bawah normal yaitu $23,5 \mathrm{~cm}$ atau bagian merah pita LiLA sehingga dapat diartikan ibu yang diukur dengan ukuran LiLa dibawah $23,5 \mathrm{~cm}$ berisiko mengalami Kekurangan Energi Kronik (KEK) (Supriasa, 2012).

Status gizi merupakan permasalahan kesehatan yang sering terjadi di negara berkembang terutama pada status gizi ibu hamil. Prevalensi kejadian KEK di negaranegara berkembang seperti Bangladesh, India, Myanmar, Nepal, Srilangka, dan Indonesia adalah $15-47 \%$ dengan BMI $<18,5 \%$. Negara yang mengalami kejadian tertinggi adalah Bangladesh yaitu $47 \%$, sedangkan Indonesia meruapakan urutan ke empat terbesar setelah India dengan prevalensi $35,5 \%$ dan yang paling rendah adalah Thailand dengan prevalensi 1525\% (Irianto, 2014).
Hasil data Profil Kesehatan Provinsi Jawa tengah (2013), Prevalensi risiko KEK wanita hamil lebih tinggi dari wanita tidak hamil. Terdapat 17 kabupaten dengan prevalensi risiko KEK pada wanita hamil di atas angka provinsi $(23,2 \%)$ yaitu Banyumas, Wonosobo, Boyolali, Klaten, Wonogiri, Rembang, Pati, Jepara, Demak, Semarang, Temanggung, Batang, Tegal, Kota Magelang, Kota Surakarta, Kota Salatiga, dan Kota Tegal. Prevalensi KEK pada wanita tidak hamil di tingkat provinsi $20,2 \%$. Terdapat 18 kabupaten dengan prevalensi KEK diatas prevalensi provinsi yaitu Cilacap, Banyumas, Banjarnegara, Kebumen, Magelang, Boyolali, Sukoharjo, Wonogiri, Rembang, Kudus, Jepara, Temanggung, Pekalongan, Tegal, Kota Magelang, Kota Salatiga, Kota Pekalongan, dan Kota Tegal. Prevalensi KEK di Jawa Tengah sebesar 74 ibu hamil dari 663 atau sekitar 11,6 $\%$ (Dinkes Jateng, 2013).

Hasil penelitian yang dilakukan oleh Hermina Humune (2013) tentang kejadian kurang energi kronik pada ibu hamil berdasarkan umur, paritas dan pendidikan di BPJ Enny Juniati Surabaya bahwa kekurangan energi kronik pada ibu hamil dipengaruhi oleh umur, paritas dan pendidikan. Dimana dengan umur yang produktif paritas tinggi dan pendidikan dasar maka proporsi kejadian KEK pada ibu hamil cukup tinggi (Hermina, 2013).

Hasil penelitian yang dilakukan oleh Gotri Marsedi, Laksmi Widajanti dan Ronny Aruben (2017) tentang hubungan sosial ekonomi dan asupan zat gizi dengan kejadian KEK pada ibu hamil bahwa tidak ada hubungan yang signifikan sosial ekonomi (pendidikan, pekerjaan, dan pendapatan keluarga) dengan kejadian KEK, sedangkan asupan zat gizi (energi, protein, dan lemak) mempunyai hubungan yang signifikan dengan kejadian KEK di wilayah puskesmas Sie Jang kecamatan Bukit Bestari Kota Tanjung Pinang.

Tingginya angka kejadian KEK ibu hamil di wilayah Kabupaten Kendal terutama di Puskesmas Kangkung. Selama tahun 2018, ibu hamil yang mengalami KEK sebanyak 132 orang $(66 \%)$. Hal ini berdampak pada kesehatan dan kesejahteraan ibu dan janin serta outcome persalinan, antara lain BBLR dan persalinan premature. Berdasarkan latar belakang dan fenomena diatas serta dampak KEK pada ibu hamil peneliti tertarik untuk melakukan penelitian tentang "Hubungan faktor 
karakterisitk, faktor maternal dan pola makan dengan kejadian kekurangan energi kronik (KEK) pada ibu hamil di wilayah kerja Puskesmas Kangkung Kabupaten Kendal" (Dinkes Kabupaten Kendal, 2018).

\section{METODE PENELITIAN \\ Jenis Penelitian}

Jenis penelitian yang digunakan dalam penelitian ini adalah penelitian deskriptif korelasional dengan pendekatan Cross Sectional.

\section{Lokasi dan Waktu Penelitian}

Penelitian ini berlokasi di Wilayah Kerja UPTD Puskesmas Kangkung 1 Kabupaten Kendal. Waktu penelitian yaitu pada Bulan September 2018 - Bulan Juli 2019.

\section{Populasi dan Sampel}

Populasi yang di gunakan dalam penelitian ini adalah ibu hamil di Wilayah Kerja UPTD Puskesmas Kangkung 1 Kabupaten Kendal sebanyak $206 \mathrm{ibu}$ hamil. Sampel penelitian sebanyak 150 ibu hamil. Teknik sampling dalam penelitian ini adalah menggunakan puposive Sampling.

\section{Pengumpulan Data}

Pengumpulan data dilakukan dengan menggunakan kuesioner karakteristik responden dan kuesioner faktor maternal dan kuesioner kejadian pola makan.

\section{Pengolahan dan Analisa Data}

Pengolahan data dilakukan dengan menggunakan komputer program SPSS. Analisis data menggunakan analisis univariat dan analisis bivariat menggunakan uji Kendall tau.

\section{HASIL PENELITIAN}

Berdasarkan tabel 1. diperoleh hasil bahwa ibu hamil yang usianya kurang dari 20 tahun 11 responden $(7,3 \%)$. Ibu hamil yang berusia 20 sampai 35 tahun sebanyak 117 responden $(78 \%)$. Sedangkan ibu hamil yang berusia lebih dari 35 tahun sejumlah 22 responden $(14,7 \%)$. Rata-rata usia ibu hamil adalah 28,63 tahun dengan usia paling muda adalah 17 tahun dan yang paling tua adalah usia 45 tahun.

Melalui hasil uji Kendall tau diperoleh nilai $p$ value yaitu $0,002 \quad(<0,05)$ maka dikatakan bahwa hipotesis diterima atau ada hubungan antara kategori usia ibu hamil dengan kejadian KEK pada ibu hamil di UPTD Puskesmas Kangkung I Kendal.

\section{Tabel 1. Distribusi Frekuensi Faktor} Maternal dan Pola Makan

\begin{tabular}{|c|c|c|}
\hline Variabel & $\mathbf{n}$ & $\%$ \\
\hline \multicolumn{3}{|l|}{ Pendidikan } \\
\hline SD & 27 & 18 \\
\hline SMP & 32 & 21,3 \\
\hline SMA & 80 & 53,3 \\
\hline PT & 11 & 7,3 \\
\hline \multicolumn{3}{|l|}{ Usia (Tahun) } \\
\hline$<20$ & 11 & 7,3 \\
\hline $20-35$ & 117 & 78 \\
\hline$>35$ & 22 & 14,7 \\
\hline \multicolumn{3}{|l|}{ Pendapatan } \\
\hline < Rp. 1.750 .000 & 142 & 94,7 \\
\hline$\geq$ Rp. 1.750 .000 & 8 & 5,3 \\
\hline \multicolumn{3}{|l|}{ Paritas } \\
\hline Primipara & 35 & 23,3 \\
\hline Multipara & 112 & 74,7 \\
\hline Grandemultipara & 3 & 2 \\
\hline \multicolumn{3}{|l|}{ Penyakit Penyerta } \\
\hline $\mathrm{Ya}$ & 126 & 84 \\
\hline Tidak & 24 & 16 \\
\hline \multicolumn{3}{|l|}{ Pola Makan } \\
\hline Baik & 130 & 80,7 \\
\hline Cukup & 4 & 2,7 \\
\hline Buruk & 16 & 10,6 \\
\hline \multicolumn{3}{|l|}{ Kejadian KEK } \\
\hline Tidak KEK & 134 & 89,3 \\
\hline KEK & 16 & 10,7 \\
\hline
\end{tabular}

Dari hasil penelitian diperoleh hasil bahwa ibu hamil dengan paritas primipara sebanyak 35 responden (23,3\%). Ibu hamil dengan paritas multipara sebanyak 112 responden $(74,7 \%)$. Sedangkan ibu hamil dengan paritas grandemultipara sebanyak 3 responden (2\%). Melalui hasil uji Kendall tau diperoleh nilai $p$ value yaitu $0,011 \quad(<0,05)$ maka dikatakan bahwa hipotesis diterima atau ada hubungan antara paritas ibu hamil dengan kejadian KEK pada ibu hamil di UPTD Puskesmas Kangkung I Kendal.

Ibu hamil yang memiliki pendidikan terakhir SD sebanyak 27 responden (18\%). Ibu hamil yang memiliki pendidikan terakhir SMP sebanyak 32 responden (21,3\%). Sedangkan ibu hamil yang memiliki pendidikan terakhir SMA sebanyak 80 responden $(53,3 \%)$, dan ibu hamil yang memiliki pendidikan terakhir Perguruan 
Tingi (PT) sebanyak 11 responden $(7,3 \%)$. Melalui hasil uji Kendall tau diperoleh nilai $p$ value yaitu $0,000 \quad(<0,05)$ maka dikatakan bahwa hipotesis diterima atau ada hubungan antara pendidikan dengan kejadian KEK pada ibu hamil di UPTD Puskesmas Kangkung I Kendal.

Tabel 2. Hubungan antara Kategori Usia Ibu Hamil, Paritas, Pendidikan, Pendapatan, Penyakit Penyerta, dan Pola Makan dengan Kejadian KEK

\begin{tabular}{|c|c|c|c|c|c|c|c|}
\hline \multirow{3}{*}{ Variabel } & \multicolumn{4}{|c|}{ Kehamilan } & \multirow{2}{*}{\multicolumn{2}{|c|}{ Total }} & \multirow{3}{*}{$P$ Value } \\
\hline & \multicolumn{2}{|c|}{ KEK } & \multicolumn{2}{|c|}{$\begin{array}{c}\text { Tidak } \\
\text { KEK } \\
\end{array}$} & & & \\
\hline & $\mathrm{n}$ & $\%$ & $\mathrm{n}$ & $\%$ & $\mathrm{n}$ & $\%$ & \\
\hline $\begin{array}{l}\text { Usia (tahun) } \\
<20 \\
20-35 \\
>35 \\
\text { Total } \\
\end{array}$ & $\begin{array}{c}6 \\
10 \\
0 \\
16\end{array}$ & $\begin{array}{c}4 \\
6,6 \\
0 \\
10,6 \\
\end{array}$ & $\begin{array}{c}5 \\
107 \\
22 \\
134\end{array}$ & $\begin{array}{c}3,3 \\
71,4 \\
14,7 \\
89,4 \\
\end{array}$ & $\begin{array}{c}11 \\
117 \\
22 \\
150\end{array}$ & $\begin{array}{c}7,3 \\
78 \\
14,7 \\
100 \\
\end{array}$ & 0,002 \\
\hline $\begin{array}{l}\text { Paritas } \\
\text { Primipara } \\
\text { Multipara } \\
\text { Grandemultipara } \\
\text { Total } \\
\end{array}$ & $\begin{array}{c}9 \\
7 \\
0 \\
16 \\
\end{array}$ & $\begin{array}{c}6 \\
4,6 \\
0 \\
10,6 \\
\end{array}$ & $\begin{array}{c}26 \\
105 \\
3 \\
134 \\
\end{array}$ & $\begin{array}{c}17,4 \\
70 \\
2 \\
89,4 \\
\end{array}$ & $\begin{array}{c}35 \\
112 \\
3 \\
150 \\
\end{array}$ & $\begin{array}{c}23,3 \\
74,7 \\
2 \\
100 \\
\end{array}$ & 0,011 \\
\hline $\begin{array}{l}\text { Pendidikan } \\
\text { SD } \\
\text { SMP } \\
\text { SMA } \\
\text { PT } \\
\text { Total } \\
\end{array}$ & $\begin{array}{c}16 \\
0 \\
0 \\
0 \\
16\end{array}$ & $\begin{array}{c}10,7 \\
0 \\
0 \\
0 \\
10,7 \\
\end{array}$ & $\begin{array}{c}11 \\
32 \\
80 \\
11 \\
134 \\
\end{array}$ & $\begin{array}{c}7,4 \\
21,3 \\
53,3 \\
7,3 \\
89,3 \\
\end{array}$ & $\begin{array}{c}27 \\
32 \\
80 \\
11 \\
150\end{array}$ & $\begin{array}{c}18 \\
21,3 \\
53,3 \\
7,3 \\
100 \\
\end{array}$ & 0,000 \\
\hline $\begin{array}{l}\text { Pendapatan } \\
>1.750 .000 \\
<1.750 .000 \\
\text { Total } \\
\end{array}$ & $\begin{array}{c}12 \\
4 \\
16 \\
\end{array}$ & $\begin{array}{r}8 \\
2,65 \\
10,65 \\
\end{array}$ & $\begin{array}{c}130 \\
4 \\
134 \\
\end{array}$ & $\begin{array}{r}86,7 \\
2,65 \\
89,35 \\
\end{array}$ & $\begin{array}{c}142 \\
8 \\
150\end{array}$ & $\begin{array}{c}94,7 \\
5,3 \\
100 \\
\end{array}$ & 0,063 \\
\hline $\begin{array}{l}\text { Penyakit Peny } \\
\text { Tidak } \\
\text { Ya } \\
\text { Total } \\
\text { Pola Makan } \\
\end{array}$ & $\begin{array}{c}\text { yert: } \\
9 \\
7 \\
16\end{array}$ & $\begin{array}{c} \\
6 \\
4,6 \\
10,6\end{array}$ & $\begin{array}{c}117 \\
17 \\
134\end{array}$ & $\begin{array}{c}78 \\
11,4 \\
89,4\end{array}$ & $\begin{array}{c}126 \\
24 \\
150\end{array}$ & $\begin{array}{c}84 \\
16 \\
100\end{array}$ & 0,030 \\
\hline $\begin{array}{l}\text { Baik } \\
\text { Cukup } \\
\text { Buruk } \\
\text { Total } \\
\end{array}$ & $\begin{array}{c}0 \\
0 \\
16 \\
16\end{array}$ & $\begin{array}{c}0 \\
0 \\
10,6 \\
10,6\end{array}$ & $\begin{array}{c}130 \\
4 \\
0 \\
134\end{array}$ & $\begin{array}{c}86,7 \\
2,7 \\
0 \\
89,4\end{array}$ & $\begin{array}{c}130 \\
4 \\
16 \\
150\end{array}$ & $\begin{array}{c}86,7 \\
2,7 \\
10,6 \\
100\end{array}$ & 0,000 \\
\hline
\end{tabular}

Ibu hamil yang memiliki pendapatan keluarga lebih dari Rp 1.750.000,00 sebanyak 142 responden $(94,7 \%)$. Sedangkan ibu hamil yang memiliki pendapatan keluarga kurang dari Rp 1.750.000,00 sebanyak 8 responden $(5,3 \%)$. Melalui hasil uji Kendall tau diperoleh nilai $p$ value yaitu $0,063 \quad(<0,05)$ maka dikatakan bahwa hipotesis ditolak atau tidak ada hubungan antara pendapatan keluarga dengan kejadian KEK pada ibu hamil di UPTD Puskesmas Kangkung I Kendal.

Ibu hamil yang tidak memiliki riwayat penyakit penyerta sebanyak 126 responden (84\%). Sedangkan ibu hamil yang memiliki riwayat penyakit penyerta sebanyak 16 responden (16\%). Melalui hasil uji Kendall tau diperoleh nilai $p$ value yaitu $0,030 \quad(<0,05)$ maka dikatakan bahwa hipotesis diterima atau ada hubungan antara riwayat penyakit penyerta ibu hamil dengan kejadian KEK pada ibu hamil di UPTD Puskesmas Kangkung I Kendal.

Berdasarkan tabel 2. diperoleh hasil bahwa ibu hamil yang memiliki pola makan baik sebanyak 130 responden $(86,7 \%)$. Ibu hamil yang memiliki pola makan cukup sebanyak 4 responden (2,7\%). Sedangkan ibu hamil yang memiliki pola makan buruk sebanyak 16 responden $(10,7 \%)$. Rata-rata pola makan yang diperoleh dari hasil kuesioner adalah 28,47 dengan usia kehamilan paling rendah 13 dan yang paling tinggi 33 .

Melalui hasil uji Kendall tau diperoleh nilai $p$ value yaitu $0,000 \quad(<0,05)$ maka dikatakan bahwa hipotesis diterima atau ada hubungan antara kategori pola makan ibu hamil dengan kejadian KEK pada ibu hamil di UPTD Puskesmas Kangkung I Kendal.

\section{PEMBAHASAN \\ Hubungan usia dengan kejadian KEK}

Hasil penelitian menunjukkan bahwa ada hubungan yang signifikan antara kategori usia ibu hamil dengan kejadian KEK diperoleh nilai $p$ value yaitu 0,002 . Hal ini menunjukkan bahwa ada pengaruh antara usia terhadap kejadian KEK. Semakin muda ( $<20$ tahun) atau semakin tua (> 35 tahun) seorang ibu yang sedang hamil akan berpengaruh terhadap kebutuhan gizi yang diperlukan. Umur muda perlu tambahan gizi yang banyak karena selain digunakan untuk pertumbuhan dan perkembangan dirinya sendiri juga harus berbagi dengan janin yang sedang dikandung. Sedangkan untuk umur yang tua perlu energi yang besar juga karena fungsi organ yang makin melemah maka memerlukan tambahan energi yang cukup guna mendukung kehamilan yang sedang berlangsung (Atika dan Siti, 2009).

Hasil penelitian ini selaras dengan hasil penelitian Efrinita (2010) yang menyatakan bahwa ada hubungan antara umur ibu dengan KEK. Terdapat ibu hamil yang berusia kurang 
dari 20 tahun sebanyak $18 \%$ di wilayah penelitian. Usia kurang dari 20 tahun merupakan ibu hamil yang beresiko dan dikhawatirkan pasokan gizi terutama protein untuk janin kurang.

Hasil penelitian yang dilakukan oleh Hermina Humune (2013) tentang kejadian kurang energi kronik pada ibu hamil berdasarkan umur, paritas dan pendidikan di BPJ Enny Juniati Surabaya bahwa kekurangan energi kronik pada ibu hamil dipengaruhi oleh umur, paritas dan pendidikan. Dimana dengan umur yang produktif paritas tinggi dan pendidikan dasar maka proporsi kejadian KEK pada ibu hamil cukup tinggi (Hermina, 2013).

\section{Hubungan paritas dengan kejadian KEK}

Hasil penelitian menunjukkan bahwa ada hubungan yang signifikan antara paritas ibu hamil dengan kejadian KEK diperoleh nilai $p$ value yaitu 0,011 . Paritas adalah status seorang wanita sehubungan dengan jumlah anak yang pernah dilahirkan (Rustam Mochtar, 2012). Paritas yang termasuk dalam faktor resiko tinggi dalam kehamilan adalah grademultipara, dimana hal ini dapat menimbulkan keadaan mempengaruhi optimalisasi ibu maupun janin pada kehamilan yang dihadapi. Dapat disimpulkan kalau paritas yang tidak lebih dari 4 tidak beresiko mengalami gangguan (Manuaba, 2010), sehingga dalam penelitian ini penulis menyimpulkan nullipara dan primipara tidak termasuk dalam resiko tinggi kehamilan.

Hasil penelitian sesuai dengan penelitian Humune (2013) tentang kejadian kurang energi kronik pada ibu hamil berdasarkan umur, paritas dan pendidikan di BPJ Enny Juniati Surabaya yang menyatakan bahwa kekurangan energi kronik pada ibu hamil dipengaruhi oleh paritas,dimana dengan paritas tinggi maka proporsi kejadian KEK pada ibu hamil cukup tinggi (Hermina, 2013).

Hasil penelitian ini berbeda dengan penelitian Efrinita (2010) yang menyatakan bahwa secara statistik tidak terdapat hubungan yang bermakna antara paritas dengan KEK.Hal ini dapat dilihat dengan hasil paling banyak yaitu ibu primigravida atau pertama kali hamil, sehingga tidak beresiko mengalami KEK.

\section{Hubungan pendidikan dengan kejadian KEK}

Hasil penelitian menunjukkan bahwa ada hubungan yang signifikan antara pendidikan ibu hamil dengan kejadian KEK diperoleh nilai $p$ value yaitu 0,000 . Pendidikan adalah upaya untuk memberikan pengetahuan sehingga terjadi perubahan perilaku positif yang meningkat (Notoatmodjo, 2012). Pendidikan formal dari ibu sering kali mempunyai asosiasi yang positif dengan pengembangan pola-pola konsumsi makanan dalam keluarga. Semakin tinggi tingkat pendidikan ibu maka semakin baik pengetahuan gizi dan semakin diperhitungkan jenis serta jumlah makanan yang dipilih untuk dikonsumsi (Sediaoetama, 2012).

Tingkat pendidikan turut menentukan mudah tidaknya ibu yang akan menyerap dan memahami pengetahuan yang diperoleh, pada umumnya semakin tinggi pendidikan seseorang ibu maka semakin baik pula tingkat pengetahuannya. Ibu yang mempunyai pengetahuan nutrisi akan memilih makanan yang lebih bergizi daripada yang kurang bergizi (Joyomartono, 2014).

Hasil penelitian selaras dengan penelitian Handayani (2013) tentang faktor yang memprngaruhi kejadian Kekurangan Energi Kronik (KEK) pada ibu hamil bahwa terdapat pengaruh yang bermakna antara pendidikan terhadap kejadian KEK pada ibu hamil di wilayah Puskesma Baturetno (Handayani, 2013).

Berdasarkan hasil penelitian yang dilakukan oleh Nurlaela tentang hubungan tingkat pendidikan dan pengetahuan dengan KEK pada ibu hamil di wilayah Puskesmas Ampana Timur (2013) menunjukkan bahwa tidak ada hubungan yang bermakna antara pendidikan dan KEK pada ibu hamil (Nurlaela, 2013).

\section{Hubungan pendapatan keluarga dengan kejadian KEK}

Hasil penelitian menunjukkan bahwa tidak ada hubungan pendapatan keluarga ibu hamil dengan kejadian KEK diperoleh nilai $p$ value yaitu 0,063 . Konsumsi makanan harus dalam jangkauan keuangan keluarga dan mengandung zat-zat gizi yang diperlukan. Perkirakan bahan makanan yang dibutuhkan dan harganya, apabila tidak sanggup dibeli dengan keuangan yang ada maka dapat dikurangi secara bertahap. Cara mengurangi pengeluaran dapat dilakukan dengan cara menurunkan kualitas beras yang dibeli karena nilai gizi beras kualitas tinggi dan kualitas 
rendah adalah sama, mengganti bahan makanan pokok beras dengan non beras, menggunakan lauk pauk yang tidak terlalu mahal, dan meninjau sayur dan buah pencuci mulut dengan cara memilih jenis sayuran dan buah yang lebih murah tanpa mengurangi kualitasnya. Sayuran dan buah tertentu dapat ditanam sendiri di pekarangan rumah untuk meringankan biaya, sehingga dengan keuangan yang minim tetap dapat memenuhi kebutuhan makanan yang bergizi tanpa harus membeli (Sediaoetama, 2012).

Hasil penelitian sesuai dengan hasil penelitian yang dilakukan oleh Rahmadi (2012) yang menyatakan bahwa tingkat pendapatan perkapita tidak berhubungan nyata dengan tingkat konsumsi energi, protein, vitamin $\mathrm{C}$ dan zat besi ibu hamil. Sementara hasil penelitian yang dilakukan oleh Oktaviana dan Patonah (2010) tentang hubungan status ekonomi dengan Kurang Energi Kronik (KEK) pada ibu hamil. Hasil penelitiannya menyatakan bahwa ada hubungan hubungan antara status ekonomi dengan Kekurangan Energi Kronik (KEK) pada responden (Oktaviana, 2010).

\section{Hubungan riwayat penyakit penyerta dengan kejadian KEK}

Hasil penelitian menunjukkan bahwa ada hubungan yang signifikan antara pendapatan keluarga ibu hamil dengan kejadian KEK diperoleh nilai $p$ value yaitu 0,030. Penyakit infeksi dapat bertindak sebagai pemula terjadinya kurang gizi sebagai akibat menurunya nafsu makan, adanya gangguan penyerapan dalam saluran pencernaan atau peningkatan kebutuhan zat gizi oleh adanya penyakit. Kaitan penyakit infeksi dengan keadaan gizi kurang merupakan hubungan timbal balik, yaitu hubungan sebab akibat. Penyakit infeksi dapat memperburuk keadaangizi dan keadaan gizi yang jelek dapat mempermudah infeksi. Penyakit yang umumnya terkait dengan masalah gizi antara lain diare, tuberkulosis, campak danbatuk rejan (Supariasa, 2012).

Menurut Suhardjo (1996) dalam Ningrum (2010), status gizi merupakan bagian penting dari status kesehatan seseorang. Tidak hanya status gizi yang mempengaruhi kesehatan tetapi status kesehatan juga mempengaruhi status gizi. Infeksi dan demam dapat menyebabkan merosotnya nafsu makan atau menimbulkan kesulitan menelan dan mencerna makanan. Parasite dalam usus seperti cacing gelang dan cacing pita bersaing dengan tubuh dalam memperoleh makanan dan dengan demikian menghalangi zat gizi kedalam arus darah. Keadaan demikian membantu terjadinya kurang gizi. Supariasa (2012) menyatakan bahwa ada hubungan yang sangat erat antara interaksi (bakteri, virus dan parasite) dengan malnutrisi.

Hasil penelitian ini sesuai dengan penelitian yang dilakukan Mulyaningrum (2009), yang berjudul "Faktor-Faktor yang Berhubungan dengan Risiko Kurang Energi Kronis (KEK) pada Ibu Hamil di Provinsi DKI Jakarta Tahun 2009" menunjukkan adanya hubungan yang bermakna antara penyakit infeksi dengan kejadian KEK.

Sesuai dengan penelitian yang dilakukan oleh Fitrianingtyas (2018) yang meneliti tentang faktor-faktor yang berhubungan dengan kejadian Kurang Energi Kronis (KEK) pada ibu hamil di Puskesmas Warung Jambu Kota Bogor. Hasil penelitiannya menyatakan bahwa ada hubungan antara penyakit infeksi dengan kejadian Kurang Energi Kronis (KEK)

\section{Hubungan pola makan dengan kejadian KEK}

Hasil penelitian menunjukkan bahwa ada hubungan yang signifikan antara pola makan ibu hamil dengan kejadian KEK, diperoleh nilai $p$ value yaitu 0,000 . Hasil penelitian menunjukkan bahwa sebagian besar ibu hamil yang memiliki pola makan baik tidak mengalami KEK, namun juga terdapat ibu hamil dengan pola makan kurang mengalami KEK, hal ini disebabkan karena ibu hamil kurang memperhatikan aspek pemenuhan makanannya sendiri yang akan berdampak pada keadaan gizi ibu hamil.

Dalam penelitian ini, ditemukan ibu hamil yang tidak mengalami KEK namun pola makannya kurang. Kondisi seperti ini perlu diperhatikan oleh ibu hamil karena akan berdampak pada kesehatan ibu dan janinnya. Ibu yang pola makannya kurang dapat diindikasikan bahwa ibu tidak tercukupi kebutuhan nutrisinya sehingga berpeluang memiliki status gizi kurang. Jika kebiasaan ini berlangsung lama maka ibu hamil akan berisiko mengalami KEK, meskipun pada saat penelitian keadaan ibu hamil dikategorikan tidak mengalami KEK. 
Adanya ibu yang memiliki pola makan kurang dapat diindikasikan bahwa ibu memiliki kebiasaan makan yang sama seperti kondisi sebelum hamil, padahal kebutuhan makanan ibu hamil 3 kali lipat lebih banyak dari sebelumnya. Berdasarkan data yang diperoleh di lapangan, diketahui bahwa lebih banyak ibu hamil yang sehari harinya sebagai ibu rumah tangga. Hal ini dapat diindikasikan bahwa aktifitas fisik yang dilakukan sebagai seorang ibu rumah tangga cenderung lebih rendah daripada ibu yang bekerja di luar rumah dengan kapasitas pekerjaan yangg membutuhkan lebih banyak tenaga. Hal ini setidaknya mengurangi pembakaran energi dalam tubuh yang dapat mengurangi cadangan energi di dalam tubuh ibu hamil. Tingkat aktifitas fisik seseorang berkaitan dengan jenis pekerjaannya. Seseorang dengan tingkat aktifitas yang berat setiap harinya dan tidak diimbangi dengan asupan makan yang adekuat maka tubuhnya lebih rentan terkena penyakit infeksi dan mengakibatkan kekurangan energi krinis (Marlenywati, 2010).

Hasil penelitian ini ditemukan adanya ibu hamil yang memiliki pola makan kurang namun dikategorikan tidak mengalami KEK.Dalam penelitian ini, juga ditemukan adanya ibu hamil yang pola makannya baik namun mengalami KEK dapat diindikasikan bahwa makanan yang dikonsumsi ibu tidak adekuat terhadap kebutuhan tubuh ibu hamil pada kondisi tertentu.

Konsumsi makanan yang adekuat untuk ibu hamil adalah yang jika dikonsumsi tiap harinya dapat memenuhi kebutuhan zat-zat gizi dalam kualitas maupun kuantitasnya. Artinya bahwa, adanya ibu yang hamil yang pola konsumsi dikategorikan baik namun mengalami KEK karena pada penelitian ini diketahui bahwa seluruh responden/ibu hamil berada pada trimester 2 dan 3 yang berarti bahwa semakin meningkatnya kebutuhan kalori/energi ibu hamil pada semester-semester akhir.

Berdasarkan WNPG (2004), tambahan kalori ibu hamil pada trimester 1 adalah 180 $\mathrm{Kkal} / \mathrm{hari}$ dan $300 \mathrm{Kkal} / \mathrm{hari}$ selama trimester 2 dan 3, sedangkan tambahan protein selama kehamilan sebesar 17 gram/hari. Kebutuhan akan energi pada trimester 1 meningkat secara minimal. Setelah itu, sepanjang trimester 2 dan 3, kebutuhan akan terus membesar sampai akhir kehamilan. Energi tambahan selama trimester 2 diperlukan untuk pemekaran jaringan ibu.
Sepanjang trimester 3, energi tambahan dipergunakan untuk pertumbuhan janin dan plasenta.

Hal ini sejalan pendapat Zulhaida (2008) dalam jurnal penelitian status gizi ibu hamil serta pengaruhnya terhadap bayi yang dilahirkan, bila ibu mengalami kekurangan gizi pada trimester III akan menimbulkan masalah terhadap ibu dan proses persalinannya, yaitu gizi kurang pada ibu hamil dapat menyebabkan resiko dan komplikasi antara lain: KEK, anemia, perdarahan, berat badan ibu tidak bertambah secara normal, dan terkena penyakit infeksi. Oleh karena itu, dalam penelitian ini meskipun pola konsumsi ibu hamil dikatakan baik namun belum cukup mampu mendukung kebutuhan nutrisi ibu hamil yang berada pada trimester-trimester akhir, sehingga masih ada ibu hamil yang memiliki pola konsumsi baik namun termasuk dalam kategori KEK.

Penelitian ini sejalan dengan penelitian yang dilakukan oleh Andi Rahmaniar (2011) di Tampa Padang Kabupaten Mamuju Sulawesi Barat, dengan nilai $\mathrm{p}=0,015$. Dimana pola makan mempengaruhi kejadian KEK pada ibu hamil, pola makan sehari-hari dari ibu hamil dipengaruhi juga dengan adanya kepercayaan memantang terhadap makanan tertentu untuk di konsumsi dengan alasan apabila dikonsumsi pada saat hamil akan mengakibatkan kecacatan pada bayi yang dilahirkan sehingga asupan makanan pada ibu hamil menjadi kurang.

\section{KESIMPULAN DAN SARAN}

Terdapat hubungan yang signifikan antara kategori usia ibu hamil dengan kejadian KEK diperoleh nilai $p$ value yaitu 0,002 . Ada hubungan yang signifikan antara paritas ibu hamil dengan kejadian KEK diperoleh nilai $p$ value yaitu 0,011. Ada hubungan yang signifikan antara pendidikan ibu hamil dengan kejadian KEK diperoleh nilai $p$ value yaitu 0,000 . Ada hubungan yang signifikan antara pendapatan keluarga ibu hamil dengan kejadian KEK diperoleh nilai $p$ value yaitu 0,063 . Ada hubungan yang signifikan antara riwayat penyakit penyerta ibu hamil dengan kejadian KEK diperoleh nilai $p$ value yaitu 0,031 . Ada hubungan yang signifikan antara pola makan ibu hamil dengan kejadian KEK diperoleh nilai $p$ value yaitu 0,000 .

Diharapkan kepada ibu hamil untuk memperhatikan dan memenuhi kebutuhan gizinya, agar terhindar dari Kekurangan Energi 
Kronik (KEK) dan aktif dalam mencari informasi dan banyak bertanya yang lebih paham tentang kesehatan khususnya terkait masalah KEK. Institusi dapat menjadikan penelitian ini sebagai jurnal sekaligus referensi penambah ilmu tentang hubungan faktor maternal dan pola makan dengan kejadian kekurangan energi kronik pada ibu hamil. Sebagai bahan wacana ilmiah untuk kepentingan pendidikan khususnya profesi keperawatan dan sebagai acuan untuk melaksanakan penelitian selanjutnya.

Kepada petugas kesehatan diharapkan memberikan penyuluhan kepada ibu hamil supaya lebih memperhatikan kesehatan dan konsumsi makanan yang bergizi selama hamil serta diadakan lintas sektor antara pemerintah dengan Dinas Kesehatan untuk melakukan pemeriksaan terhadap ibu hamil agar dapat melakukan tindakan pencegahan terhadap ibu hamil yang berisiko KEK. Bagi peneliti selanjutnya, untuk dapat melakukan penelitian dengan menggunakan variabel yang lain karena masih banyak faktor-faktor lain yang berhubungan dengan kejadian KEK pada ibu hamil dan dicari kekuatan hubungannya.

\section{DAFTAR PUSTAKA}

Adam, Nurlaela. (2013). Skripsi. Hubungan Tingkat Pendidikan dan Pengetahuan dengan Kekurangan Energi Kronik (KEK) pada Ibu Hamil di Puskesmas Ampana Timur Kecamatan Ampana Kota.

Aisyah. Rusnoto. Nor A. (2013). Budaya Pantang Makan, Status Ekonomi, dan Pengetahuan Zat Gizi Ibu Hamil Trimester III dengan Status Gizi.Vol.4. No. 1: JIKK

Dinas Kesehatan, Jateng. (2013). Profil
Kesehatan Provinsi Jawa Tengah Tahun 2013. Semarang: Dinkes Jateng

Gotri Marsedi, Laksmi Widajanti dan Ronny Aruben. (2016). Hubungan Sosial Ekonomi Dan Asupan Zat Gizi Dengan Kejadian KEK Pada Ibu Hamil Di Wilayah Puskesmas Sei Jang Kecamatan Bukit Bestari Kota Tanjung Pinang Tahun 2016. Volume 5. Nomer 3. ISSN: 2356-3346.

Handayani. Husna. (2013). Faktor yang Mempengaruhi Kejadian Kekurangan Energi Kronik pada Ibu Hamil.

Irianto, Koes. (2014). Gizi Seimbang dalam Kesehatan Reproduksi. Bandung: Alfabeta.

Kementrian Kesehatan RI. (2015). Rencana Strategi Kementrian kesehatan Tahun 2015-2019. Jakarta: Kemenkes.

Manuaba, I. B.G. (2010). Memahami Kesehatan Reproduksi Wanita (ed.2). Jakarta: EGC.

Oktaviana dan Patonah (2010).Hubungan Status Ekonomi dengan Kekurangan Energi Kronik pada Ibu Hamil di Puskesmas Ngambon Kabupaten Bojonegoro. Volume 1. Nomer 1. Asuhan Kesehatan.

Supriasa. (2012). Penilaian Status Gizi. Jakarta. ECG.

Soediaoetama, Djaeni. (2000). Ilmu Gizi Untuk Mahasiswa Profesi. Dian Rakyat. Jakarta.

Notoadjmojo. (2012). Metode Penelitian Kesehatan. Edisi Revisi. Jakarta: PT. Rineka Cipta. 